\title{
Research Note \\ In Search of the Narwhal: Ethical Dilemmas in Ecotourism
}

\author{
Ralf Buckley \\ International Centre for Ecotourism Research, Griffith University, \\ Southport QId, Australia
}

\section{Introduction}

Can one be an unethical ecotourist? Here I set out to show that this question is neither trivial nor straightforward.

Most definitions of ecotourism, even the more restrictive (Buckley, 1994) focus on observable criteria such as tourism products and settings, management of environmental impacts, guided interpretation for clients, and perhaps some contribution to conservation (Buckley, 1994, 2003; Fennell, 1999; Weaver, 2001). Certainly, there are complexities in interpreting and implementing any of these (Buckley, 2003), but these are second-order.

Demanding that ecotourism be defined by ethical rather than behavioural considerations is very different. Definitions of ethics, whether philosophical, professional or general, are based on morals and require individuals to make moral judgements. This is not the same as requiring people to follow rules of behaviour, even if these rules are labelled as codes of ethics rather than codes of conduct or legal regulations.

The ethical theme as been quite pervasive in the ecotourism literature, raised especially by authors such as Honey (1999) and Malloy and Fennell (1998). Most recently Fennell (2004) has argued that a responsible ecotourism industry necessarily involves moral underpinnings, in the form of theoretical and practical reverence for nature. More generally, Malloy and Fennell (1998) and Fennell (2004) argue that whilst most businesses 'feel that ethics are only useful if they are good for business', ecotourism should be 'based on principled values and ethics.'

I do not disagree with this philosophy. But as outlined below, I do not think that an ethical test can easily be incorporated into operational criteria for any practical application of ecotourism. Therefore, I would argue that it is not in fact realistic to define ecotourism in ethical terms.

If my argument is accepted, then unethical ecotourists are perfectly possible. This position may be repugnant to many readers. So this is not a trivial issue. Indeed, it is a very complex one. To illustrate the difficulties, let us consider a real-life case study, outlined below.

\section{Case Study: High Arctic Sea Kayak Tour}

There are relatively few commercial seakayak tours in the High Arctic. The season is short, access expensive, and conditions can be difficult, so tours are 
expensive and appeal only to experienced seakayakers. One such tour is operated by Blackfeather Inc, based in Ontario, Canada (Blackfeather, 2005). This company operates a two-week self-supported seakayak trip out of Pond Inlet near the northern tip of Baffin Island. The tour features a search for narwhal in a number of steep-sided narrow sounds, and is advertised as 'In search of the narwhal' (Blackfeather, 2005).

The trip uses collapsible kayaks, and these together with all camping equipment, food and other supplies are brought in by plane specifically for the trip, carried as excess baggage by the guides and clients. The tour starts with a speedboat shuttle to the furthermost point, taking about five hours. The kayaks are then assembled and loaded, and the group paddles back to Pond Inlet over a period of 10 days or so. When I took part in this trip we saw narwhal near the drop-off point, but not subsequently. Seakayaking in this area is safe only during the relatively brief summer break-up of the ice, and this takes place after nesting seabirds have already migrated south. The landscape is spectacular but rather bleak, and the weather variable.

\section{Local Communities and Narwhal Hunting}

There is only a short period of the year when these sounds are accessible by boat, and many of the Inuit families in Pond Inlet and other settlements take advantage of the weather and the open water to establish fishing and hunting camps on the shores of the sounds. Whilst such camps no doubt have a long traditional history, technologies have changed greatly. A number of locals now have large, fast and seaworthy boats, often purchased with Canadian Government assistance, and they also have high-powered highcalibre modern rifles, which they use to shoot at surfacing narwhal and other whales. Narwhal are hunted partly for the tusks, and partly for the blubber, which is known locally as muktuk and considered a great delicacy. International trade in narwhal tusks and other body parts is prohibited under the Convention on International Trade in Endangered Species (CITES, 2005). According to local Inuit, however, several cruise ships visit Pond Inlet each year, and their passengers are always keen to buy narwhal tusks. The majority of purchasers, reportedly, are from Asian nations which are not signatory to CITES.

\section{Evidence of Hunting}

How did we know that narwhal were being killed? We saw numerous boats and heard a number of rifle shots. Indeed, when we looked at these boats through our binoculars we often saw their occupants looking back at us through their telescopic sights, a somewhat unnerving experience. We saw the flensed carcass of a young narwhal drifting near a beach. And most importantly, we met Inuit hunters who showed us narwhal tusks, with the root portions still blood-covered, wrapped in blankets inside their fishing boats. The Inuit were friendly and likeable people, clearly proud of their prowess, but clearly also aware that taking tusks is frowned upon by Canadian Government officials. They showed us their boats, their rifles, and 
the tusks, and told us who buys them; but they did so surreptitiously and spoke to us individually, without witnesses.

\section{Community-centred Perspectives}

From the perspective of the individual Inuit hunters, this arrangement may seem quite satisfactory. As with Indigenous peoples in other developed nations (such as Australia), they receive taxpayer-funded subsidies which on a per capita basis are perhaps quite substantial relative to, e.g. average income in the country concerned. On the other hand, the aggregate value of these subsidies is miniscule in comparison with the value of natural resources extracted from traditional lands by colonial industries. Hence it may seem quite reasonable to the Inuit in Pond Inlet, that some members of their community have high-speed and seaworthy fishing vessels provided by the Canadian Government. Such vessels, however, need maintenance and fuel; and if seakayaking tourists will pay for the all-day trip out to where the narwhal congregate, that is remarkably convenient. And once there, it would clearly be very inefficient to return to Pond Inlet and then set out on a separate hunting trip to the same place. It makes far more sense to drop the tourists off and then go directly to hunt narwhal. And the profit from the charter, and from the later sales of narwhal tusks, provides the cash income to buy goods from the trading co-op in Pond Inlet. Narwhal were hunted traditionally, albeit in much smaller numbers and with very different technologies. Perhaps narwhal numbers are decreasing. But there are many hunters, and even if one hunter stops, the others will continue. Besides, Europeans hunted many of their species into extinction, so why should they tell Inuit peoples how to manage narwhal.

\section{Conservation-centred Perspectives}

In the eyes of the conservation biologist the situation is rather different. Narwhal are endangered. Inuit are not. Inuit used to hunt narwhal for subsistence, whereas now they hunt them for cash. Traditionally the hunt was carried out using handmade kayaks and harpoons; modern technologies are very different. Yes, distant ancestors of modern Canadians took resources from many traditional Inuit lands; and modern international corporations continue to do so. But this is nothing to do with the narwhal. Traditionally, Inuit villages may not have set limits on narwhal hunts; but the Canadian Inuit are now part of Canada, and the Canadian nation provides them with much of their current lifestyle and material goods, including both boats and firearms. They therefore have an obligation to observe Canadian law, including that relating to the hunting of narwhal and trade in narwhal tusks.

\section{Tourist Perspectives}

Perspectives of fee-paying tour clients may depend on the attitudes and experience of the client concerned. For some tourists, a 10-day High Arctic seakayaking holiday represents extreme adventure, where the major goal is simply to complete the trip. On our trip, for example, there was an older couple who were particularly concerned to paddle not just to the normal take-out point 
near Pond Inlet, but right back to Pond Inlet itself. When we did see narwhal, this couple watched from onshore rather than paddling out.

For our two guides, in contrast, a trip such as this is an easy and routine exercise, unless an unexpected and extended period of bad weather sets in. We may have been travelling in collapsible kayaks above the Artic Circle, but we were generally close to shore, protected from open ocean swell, and by no means alone: we saw a number of Inuit camps and fishing boats which could have rescued us if need be, and the guides did have radio contact, though they kept this concealed from the clients.

Another of the tour clients had previous seakayaking experience in Greenland, of which he seemed rather proud. He was interested in narwhal, but also seemed somewhat frightened of them. He was concerned about narwhal hunting, but perhaps ambivalent because he wanted to identify with the Greenlanders and hence perhaps indirectly with the Canadian Inuit.

\section{Personal Impressions}

For myself, I knew that Canadian First Nations peoples now hunt whales with rifles and outboard-powered fishing boats. I was not surprised to find that some members of the Pond Inlet Inuit community hunt narwhal, whereas others make money from narwhal tourism. I was familiar with issues relating to the use of modern technologies by indigenous peoples to hunt species which in the past were hunted only by traditional means; and to hunt for cash whereas traditionally they hunted for subsistence or cultural reasons. Other examples include dugong hunted by Aborigines in Australia; birds of paradise in Papua New Guinea; and an enormous range of terrestrial mammals throughout Africa, Asia and South America.

Naively, however, I had not expected that there would be so close a link between tourism and hunting, with the former effectively providing fuel for the latter. Not surprisingly, the few narwhal we saw dived as soon as they became aware of our boats, presumably since they have come to associate boats with hunting. Naturally, this greatly reduces the enjoyment available from watching narwhal, which after all was the main lure of the trip. Similar issues apply in areas of Africa where hunting concessions are immediately adjacent to national parks or photo safari concessions (Buckley, 2003).

\section{Ethical Issues}

From a cultural perspective, selling narwhal tusks to international cruise ship passengers rather than local carvers represents a cultural change; but not a very large one relative to other cultural changes which the Pond Inlet Inuit have experienced. From an ethical or animal-rights perspective, a narwhal shot with a rifle bullet is unlikely to die immediately; but neither is a narwhal speared with a traditional harpoon, so once again the change is minor.

From a conservation perspective, the changes are much more significant. In ecological terms, the critical issue is neither why the narwhal are killed nor how, but how many. Where individual animal parts can be sold for large cash prices, people will typically kill many more than if they are hunted solely for subsistence. This applies equally to narwhal tusks in the High 
Arctic, elephant ivory in Africa, tiger penises in Asia, or grizzly bear gall bladders in Russia. And with modern weapons, hunters can generally kill many more animals in a much shorter time than they could have done by traditional means.

It is argued by some that trophy hunting for sport can contribute to conservation (see, e.g. Buckley, 2003: 208-212). Perhaps so, where the numbers, ages and sexes of animals taken are predetermined by knowledgeable wildlife biologists, and the hunt is controlled by well-policed regulations.

That does not, however, seem to be the case for the Pond Inlet narwhal hunt. The narwhal populations are indeed studied by Canadian marine biologists, and narwhal hunting is regulated by Canadian Government agencies which specify maximum annual harvests and do indeed fly aerial patrols. This harvest, however, is intended for traditional cultural reasons, namely the supply of narwhal muktuk as a cultural food delicacy, and a limited supply of narwhal tusks for traditional art. It is not intended to supply narwhal tusks for cash sales to international buyers, since this is strictly prohibited under CITES. Effectively, therefore, from a Canadian Government perspective it is illegal poaching for cash under the guise of a legal hunt for traditional cultural reasons.

\section{Ethical Options}

Under such circumstances, how should an ethical ecotourist behave? Should we have been more concerned about the narwhal we came to watch, or the Inuit community our money was helping to support? Should we, as short-term visitors from far away, have attempted to remonstrate with local hunters and fishermen who have spent their entire lives in the area, winter as well as summer? What could we possibly say in a brief encounter on a windswept beach, that would lead them to trust our opinion rather than their own experience, particularly since we were neither narwhal biologists nor familiar with narwhal population dynamics, narwhal hunt regulations nor permissible annual narwhal harvests? We knew only that narwhal are endangered, that they are listed under CITES, and that during our brief period in the sounds around Pond Inlet, the number of narwhal tusks we saw was more than $10 \%$ of the total number of live narwhal we saw.

Should we, perhaps, have reported what we saw to Canadian Government fisheries officers? And if so, what could they do? Should we, as tour clients, have relied on our guides to report to the tour company's head office, for them in turn to make an official report? Should we, perhaps, have drawn the company's attention to these issues, so that as a long-term commercial charter client of the fishing boat operators, they could raise the issue in a tactful, culturally appropriate and unhurried way during future negotiations? We did, in fact, do some of these things but not others. I will lead readers to consider what they themselves think would have been appropriate and useful in the circumstances.

Narwhal are endangered and Inuit are not. In my own view, the survival of narwhal is more important than the cultural traditions of Inuit. It is certainly more important than the opportunity for particular individual Inuit to profit 
from illegal sale of narwhal tusks to rich Asian cruise boat passengers. But others may view the issues differently. In addition, it is easy for me to express these opinions whilst sitting comfortably in a subtropical city. It would be considerably more contentious to do so whilst travelling in a fishing boat in the High Arctic. Particularly, for example, if that fishing boat had recently rescued a group of inexperienced tourists from a set of swamped seakayaks. Not, I should add, that any of us capsized. But we might have. So, did I and my fellow ecotour clients act ethically, or not? Does the tour company act ethically in running these tours, or not? If not, why not? And if not, are we still ecotourists?

\section{Conclusions}

It seems to me that no matter how concerned we may be, as Fennell (2004) encourages, to take an ethical approach to ecotourism, it is in fact quite difficult to establish 'a common pool of core values which allow us to articulate what it is that ecotourism must be' (Fennell, 2004: 119). As I have tried to show in the example above, ecotourism may involve ethical issues which are not necessarily straightforward, particularly where ethical concerns relating to endangered species conflict with ethical concerns relating to Indigenous or impoverished peoples, as is quite often the case.

Perhaps there is a possible resolution. We expect doctors and other professionals to act ethically, but we do not define medicine in terms of ethics. Perhaps we can define ecotourism without reference to ethical criteria, but still expect ecotourists to act ethically. Sounds good? OK, then what should we have done, as ethical ecotourists? And what, if anything, should the tour company do?

\section{Correspondence}

Any correspondence should be directed to Ralf Buckley, Director, International Centre for Ecotourism Research, Griffith University, Parklands Drive, Southport Qld 4215, Australia (R.Buckley@griffith.edu.au).

\section{References}

Blackfeather Inc. (2004) In Search of the Narwhal. On WWW at http://www.blackfeather. com/kayak/kayak_pondinlet.htm. Accessed 6.1.05.

Buckley, R.C. (1994) Ecotourism: A framework. Annals of Tourism Research 21, 661-669.

Buckley, R.C. (2003) Case Studies in Ecotourism. Oxford: CAB International.

CITES (2005) Convention on International Trade in Endangered Species of Wild Fauna and Flora. On WWW at http://www.cites.org. Accessed 6.1.05.

Fennell, D.A. (1999) Ecotourism: An Introduction. New York: Routledge.

Fennell, D.A. (2004) Deep ecotourism: Seeking theoretical and practical reverence. In T.V. Singh (ed.) New Horizons in Tourism: Strange Experiences and Stranger Practices. Wallingford: CABI Publishing.

Honey, M. (1999) Ecotourism and Sustainable Development: Who Owns Paradise? Washington, DC: Island Press.

Malloy, D.C. and Fennell, D.A. (1998) Ecotourism and ethics: Moral development and organisational cultures. Journal of Travel Research 26, 47-56.

Weaver, D.B. (2001) The Encyclopedia of Ecotourism. Wallingford: CABI Publishing. 